\title{
Glucagon receptor antagonist and GIP agonist combination for diet-induced obese mice
}

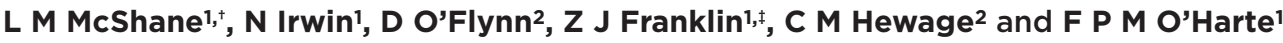

1SAAD Centre for Pharmacy and Diabetes, University of Ulster, Coleraine, Northern Ireland, UK ${ }^{2}$ Conway Institute of Biomolecular and Biomedical Research, UCD, Belfield, Dublin 4, Ireland ( ${ }^{+} \mathrm{L}$ McShane is now at School of Life Sciences, Faculty of Health and Life Sciences, University of Liverpool, Liverpool, UK)

(₹Z J Franklin is now at Diabetes Research Group, Division of Diabetes and Nutritional Sciences, King's College London, London, UK)
Correspondence should be addressed to $\mathrm{F}$ O'Harte Email fpm.oharte@ulster.ac.uk

\begin{abstract}
Ablation of glucagon receptor signaling represents a potential treatment option for type 2 diabetes (T2DM). Additionally, activation of glucose-dependent insulinotropic polypeptide (GIP) receptor signaling also holds therapeutic promise for T2DM. Therefore, this study examined both independent and combined metabolic actions of desHis ${ }^{1} \mathrm{Pro}^{4} \mathrm{Glu}^{9}$ (Lys ${ }^{12 P A L}$ )-glucagon (glucagon receptor antagonist) and $\mathrm{D}-\mathrm{Ala}{ }^{2} \mathrm{GIP}$ (GIP receptor agonist) in diet-induced obese mice. Glucagon receptor binding has been linked to alpha-helical structure and desHis ${ }^{1} \mathrm{Pro}^{4} \mathrm{Glu}^{9}$ (Lys $\left.{ }^{12} \mathrm{PAL}\right)$-glucagon displayed enhanced alpha-helical content compared with native glucagon. In clonal pancreatic BRIN-BD11 beta-cells, desHis ${ }^{1} \mathrm{Pro}^{4} \mathrm{Glu}^{9}\left(\mathrm{Lys}^{12} \mathrm{PAL}\right)$-glucagon was devoid of any insulinotropic or CAMP-generating actions, and did not impede D-Ala ${ }^{2}$ GIP-mediated $(P<0.01$ to $P<0.001)$ effects on insulin and cAMP production. Twice-daily injection of desHis ${ }^{1} \mathrm{Pro}^{4} \mathrm{Glu}^{9}$ (Lys ${ }^{12} \mathrm{PAL}$ )-glucagon or $\mathrm{D}-\mathrm{Ala}^{2} \mathrm{GIP}$ alone, and in combination, in highfat-fed mice failed to affect body weight or energy intake. Circulating blood glucose levels were significantly $(P<0.05$ to $P<0.01)$ decreased by all treatments regimens, with plasma and pancreatic insulin elevated $(P<0.05$ to $P<0.001)$ in all mice receiving D-Ala ${ }^{2}$ GIP. Interestingly, plasma glucagon concentrations were decreased $(P<0.05)$ by sustained glucagon inhibition (day 28 ), but increased $(P<0.05)$ by D-Ala2GIP therapy, with a combined treatment resulting in glucagon concentration similar to saline controls. All treatments improved $(P<0.01)$ intraperitoneal and oral glucose tolerance, and peripheral insulin sensitivity. D-Ala ${ }^{2}$ GIP-treated mice showed increased glucoseinduced insulin secretion in response to intraperitoneal and oral glucose. Metabolic rate and ambulatory locomotor activity were increased $(P<0.05$ to $P<0.001)$ in all desHis ${ }^{1} \mathrm{Pro}^{4} \mathrm{Glu}^{9}\left(\mathrm{Lys}^{12} \mathrm{PAL}\right)$-glucagon-treated mice. These studies highlight the potential of glucagon receptor inhibition alone, and in combination with GIP receptor activation, for T2DM treatment.
\end{abstract}

\author{
Key Words \\ - glucagon \\ - glucose-dependent \\ insulinotropic \\ polypeptide (GIP) \\ - glucose homeostasis \\ - insulin secretion \\ - insulin sensitivity \\ - glucagon receptor \\ antagonist \\ - GIP receptor agonist \\ - diet-induced obese \\ diabetic mice
}

Journal of Endocrinology (2016) 229, 319-330
() 2016 Society for Endocrinology Printed in Great Britain
Published by Bioscientifica Ltd. 


\section{Introduction}

Through advances in our understanding of the pathways involved in glucose homeostasis, and an appreciation that type 2 diabetes (T2DM) is a bihormonal disorder, it is clear that abnormalities of insulin secretion and action in T2DM are present in the setting of glucagon excess (Unger $\&$ Cherrington 2012). Thus, improved control of glucagon signaling represents a rational therapeutic target for T2DM. In agreement with this, early proof-of-concept studies using the orally available glucagon receptor antagonist, Bay 27-9955, have shown initial promise in humans (Petersen \& Sullivan 2001). Additionally, more recent clinical trials with similar orally available glucagon receptor inhibitors, MK-0893 and LY-2409021, reveal further potential for the treatment of T2DM (Xiong et al. 2012, Kelly et al. 2015). A separate, but somewhat comparable approach, to reduce glucagon receptor expression through the use of antisense oligonucleotides, has also reached Phase 2 clinical trials (Sehgal et al. 2013). However, the ultimate approval of these types of low-molecular-weight therapies will depend upon specificity and off-target effects, toxicity, and potential for immune responses (Peng et al. 2014, Kelly et al. 2015, Lefèbvre et al. 2015).

Therefore, we have recently characterized the novel peptide-based glucagon receptor antagonist, desHis ${ }^{1} \mathrm{Pro}^{4} \mathrm{Glu}^{9}\left(\mathrm{Lys}^{12} \mathrm{PAL}\right)$-glucagon $\left(\mathrm{O}^{\prime}\right.$ Harte et al. 2014), that represent a more specific approach to inhibit glucagon receptor action. Indeed, this peptide analog induced significant improvements in metabolic control following a chronic dosing regimen in diet-induced obese (DIO) as well as ob/ob diabetic mice ( $\mathrm{O}^{\prime}$ Harte et al. 2014). Importantly, we did not observe any evidence of adverse effects, and further studies in normal mice indicate that this peptide-based glucagon receptor antagonist represents a safe and effective treatment option for T2DM (Franklin et al. 2014). Interestingly, $\mathrm{Mu}$ and coworkers reported that coadministration of the glucagon antagonist, Cpd-A, with a dipeptidylpeptidase-4 (DPP-4) inhibitor in diabetic mice resulted in additional improvements in glycemic control when compared with either treatment alone (Mu et al. 2011). It follows that a combined therapy of a glucagon receptor antagonist with an incretin-based drug could offer an advantageous approach for the treatment of T2DM.

The incretin hormones, glucose-dependent insulinotropic polypeptide (GIP) and glucagon-like peptide-1 (GLP-1), are recognized to account for approximately $50-70 \%$ of insulin secretion following a meal (Nauck et al. 1986). However, this incretin contribution to postprandial insulin release falls to less than 20\% in T2DM (Nauck et al. 1986). The reduction is attributable to decreased GLP-1 release (Vilsbøll et al. 2001) and resistance to the insulinotropic actions of GIP in T2DM (Nauck et al. 1993). Accordingly, enzymatically stable GLP-1 mimetics that enhance circulating physiological levels of GLP-1 have gained notable success in the T2DM clinic (Gupta 2013, Chaplin \& Joseph 2014), whereas GIP mimetics are yet to reach the clinic due to insensitivity in T2DM patients (Nauck et al. 1993). More encouragingly, GIP resistance in T2DM appears to be reversible in both animals and human through tight glycemic control or combinational drug therapy (Meneilly et al. 2003, Piteau et al. 2007, Højberg et al. 2009). In addition to this, there is a suggestion that GIP, unlike GLP-1, can promote glucagon release (Meier \& Nauck 2004, 2015), which would further detract from its therapeutic efficacy in T2DM. Thus, coadministration of a specific glucagon receptor antagonist (O'Harte et al. 2014), with a stable long-acting GIP mimetic, such as D-Ala ${ }^{2}$ GIP (Hinke et al. 2002, Gault et al. 2003), should offer a meaningful therapeutic advantage.

To evaluate the potential of combined glucagon receptor inhibition and GIP receptor activation in T2DM, we have investigated the effects of subchronic treatment with the peptide-based glucagon receptor antagonist, desHis ${ }^{1} \mathrm{Pro}^{4} \mathrm{Glu}^{9}\left(\mathrm{Lys}^{12} \mathrm{PAL}\right)$-glucagon, and $\mathrm{D}^{-\mathrm{Ala}^{2} \mathrm{GIP}}$ in DIO mice fed a high-fat diet. The results provide experimental evidence that GIP mimetics may prove to be surprisingly useful for the treatment of T2DM when combined with a glucagon receptor antagonist.

\section{Materials and methods}

\section{Peptide synthesis}

Glucagon, D-Ala ${ }^{2} \mathrm{GIP}$, and desHis ${ }^{1} \mathrm{Pro}^{4} \mathrm{Glu}^{9}\left(\mathrm{Lys}^{12} \mathrm{PAL}\right)-$ glucagon were produced ( $>95 \%$ purity) by Fmoc solid-phase peptide synthesis and purchased from GL Biochem Ltd (Shanghai, China). All peptides were further characterized in-house using matrix-assisted laser desorption ionization-time-of-flight (MALDI-TOF) mass spectrometry, as described previously (O'Harte et al. 2013).

\section{Circular dichroism (CD)}

$\mathrm{CD}$ spectra for glucagon and desHis ${ }^{1} \mathrm{Pro}^{4} \mathrm{Glu}^{9}\left(\mathrm{Lys}^{12} \mathrm{PAL}\right)-$ glucagon were acquired at the far-UV region (190-250 nm) using a JASCO J-810 spectropolarimeter.

Published by Bioscientifica Ltd. 
Peptide samples were prepared by dissolving the analogs in water or $20 \mathrm{mmol} / \mathrm{L}$ phosphate buffer at $\mathrm{pH} 7.0$ to a final concentration of $30 \mu \mathrm{M}$, and the concentrations of trifluoroethanol (TFE) used was 15, 30, 50, and 70\% for each peptide. Parameters used for CD experiments were response time of $2 \mathrm{~s}$, bandwidth of $1 \mathrm{~nm}$, scanning speed of $50 \mathrm{~nm} / \mathrm{min}$, and a data pitch of $0.2 \mathrm{~nm}$. All spectra were acquired at $25^{\circ} \mathrm{C}$ by accumulation of 15 scans in a $1 \mathrm{~mm}$ quartz cell, and the baseline corrected. Calculation of alpha-helical and beta-sheet content was carried out by the K2D3 program using the DICHROWEB web interface (Louis-Jeune et al. 2012).

\section{Acute in vitro insulin release and CAMP measurements}

BRIN-BD11 cells were cultured in RPMI-1640 culture medium containing $10 \% \mathrm{v} / \mathrm{v}$ FBS and $11.1 \mathrm{mmol} / \mathrm{L}$ glucose, and were seeded at a density of $1 \times 10^{-5}$ cells/well in 24-well plates for insulin release studies or $8 \times 10^{4}$ cells/well in 96-well plates for cAMP studies. Cells were allowed to attach overnight at $37^{\circ} \mathrm{C}$ in a LEEC incubator (Laboratory Technical Engineering, Nottingham, UK) in an atmosphere of $5 \% \mathrm{CO}_{2}$ and $95 \%$ air. Before insulin and cAMP studies, the tissue culture medium was removed and cells were preincubated with $1 \mathrm{~mL}$ KRB buffer ( $\mathrm{pH} 7.4$ ) supplemented with bovine serum albumin $(0.5 \% \mathrm{w} / \mathrm{v})$, containing $1.1 \mathrm{mmol} / \mathrm{L}$ glucose, at $37^{\circ} \mathrm{C}$ for $40 \mathrm{~min}$. Test incubations were conducted at $5.6 \mathrm{mmol} / \mathrm{L}$ glucose over a $20 \mathrm{~min}$ incubation period, using individual and combined peptide treatments as shown in the figures. For insulin release, supernatants were removed and frozen at $-20^{\circ} \mathrm{C}$ before measurement of insulin by radioimmunoassay (Flatt \& Bailey 1981). For cAMP measurements, cells were lysed and total cAMP content was determined using a commercially available chemiluminescent cAMP immunoassay kit (R\&D Systems).

\section{Animals}

NIH Swiss male mice (Harlan Ltd, Oxon, UK) were used at 18 weeks of age. The animals were housed individually in an air-conditioned room at $22 \pm 2^{\circ} \mathrm{C}$ with a $12 \mathrm{~h}$ light: $12 \mathrm{~h}$ darkness cycle (lights off between 20:00 and 08:00 h). All animals had free access to drinking water and a high-fat diet (45\% fat, 35\% carbohydrate, and $20 \%$ protein, Dietex International Ltd, Witham, Essex, UK) for 100 days before the commencement of studies. Obesity and glycemic dysregulation were clearly manifested compared with agematched mice maintained on normal laboratory chow (10\% fat, $30 \%$ protein, and $60 \%$ carbohydrate, Trouw Nutrition, Cheshire, UK) as verified by body weight and blood glucose analyses. All experiments were conducted in accordance with the UK Animals (Scientific Procedures) Act 1986, under project licences approved by the local Ethical Committee.

\section{Study design}

Mice received twice-daily intraperitoneal (i.p.) injections of saline $(0.9 \% \mathrm{NaCl} \mathrm{w} / \mathrm{v})$ at $10: 00$ and $16: 30 \mathrm{~h}$ over a 6 -day acclimatization period. Following this, mice received twice-daily i.p. administration (10:00 and $16.30 \mathrm{~h}$ ) of saline vehicle $(0.9 \% \mathrm{NaCl} \mathrm{w} / \mathrm{v})$ or desHis ${ }^{1} \mathrm{Pro}^{4} \mathrm{Glu}^{9}\left(\mathrm{Lys}^{12} \mathrm{PAL}\right)$ glucagon alone, D-Ala ${ }^{2} \mathrm{GIP}$ alone, or a combination of both peptides (all treatments at $25 \mathrm{nmol} / \mathrm{kg}$ body weight) over a 28-day period. Doses were chosen based on our previous extensive in vivo assessments with glucagon antagonist and GIP agonist peptides (Martin et al. 2013, O'Harte et al. 2014). Food intake was monitored daily, whereas body weight, circulating blood glucose, and plasma insulin concentrations were assessed at 3-4-day intervals in non-fasted mice at 09:00 $\mathrm{h}$ before the normal morning $10: 00 \mathrm{~h}$ peptide administration. At the end of the treatment period, oral and i.p. $(18 \mathrm{mmol} / \mathrm{kg}$ bw) glucose tolerance tests were performed in overnightfasted mice. In addition, an insulin sensitivity $(10 \mathrm{U} / \mathrm{kg} \mathrm{bw})$ test was also performed in non-fasted mice. At termination, pancreatic tissue was excised and insulin content was measured following extraction with $5 \mathrm{~mL} / \mathrm{g}$ of ice-cold acid ethanol (75\% ethanol, $23.5 \%$ water, $1.5 \%$ concentrated $\mathrm{HCl}$ ).

\section{Measurement of metabolic rate and locomotor activity}

Metabolic rate and locomotor activity were measured using an Oxymax Complex Laboratory Animal Monitoring System or CLAMS (Columbus Instruments, $\mathrm{OH}$, USA) on day 28. Mice were acclimatized to the air-tight metabolic chambers for $18 \mathrm{~h}$ before the commencement of observations. Oxygen consumption and carbon dioxide production were monitored for $30 \mathrm{~s}$ at $15 \mathrm{~min}$ intervals over a period of $24 \mathrm{~h}$, and respiratory exchange ratios (RER's) were produced to calculate energy expenditure using the following equation: $(3.815+1.232 \times \mathrm{RER}) \times \mathrm{VO}_{2}$. Ambulatory locomotor activity 
was assessed using the optical beams (Opto M3, Columbus Instruments, $\mathrm{OH}, \mathrm{USA}$ ). Consecutive photo-beam breaks were scored as an ambulatory movement. Activity counts in $X$ - and $Z$-axes were recorded each minute for $24 \mathrm{~h}$.

\section{Biochemical analyses}

Blood samples were collected from the cut tip on the tail vein of conscious mice into chilled fluoride/heparin glucose microcentrifuge tubes (Sarstedt, Numbrecht, Germany) at the time points indicated in the figures. Blood glucose was measured directly using a handheld Ascencia Contour blood glucose meter (Bayer). For plasma insulin analysis, blood samples were immediately centrifuged using a Beckman microcentrifuge (Beckman Instruments, Galway, Ireland) for $1 \mathrm{~min}$ at $13,000 \mathrm{~g}$ and stored at $-20^{\circ} \mathrm{C}$. Plasma and pancreatic insulin was assayed by a modified dextran-coated charcoal RIA
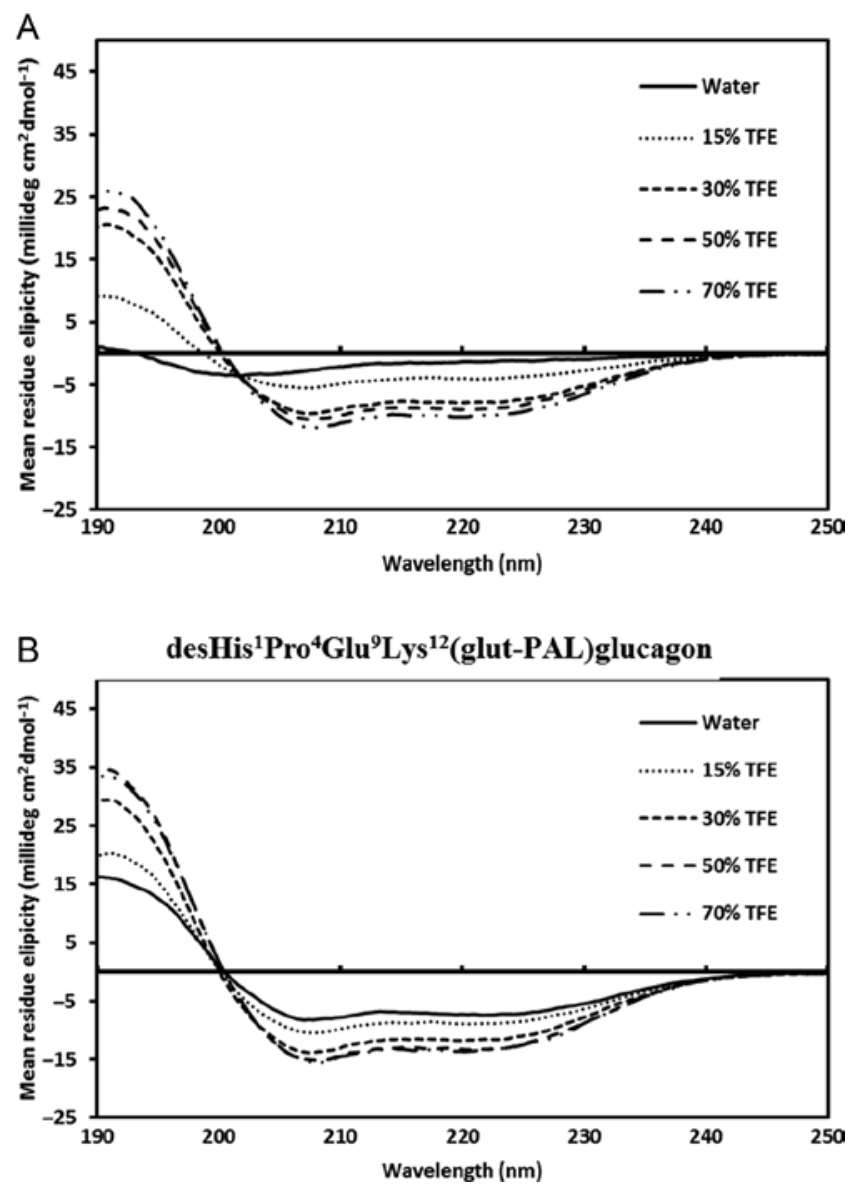

Figure 1

Circular dichrosim spectra of (A) glucagon and (B) desHis ${ }^{1}$ Pro $^{4} \mathrm{Glu}^{9}$ (Lys ${ }^{12} \mathrm{PAL}$ )-glucagon. Spectra were observed in the far-UV region under different concentrations of TFE, as indicated in the figure.
(Flatt \& Bailey 1981). In addition, a terminal blood sample was also collected for the measurement of plasma glucagon via a sandwich immunoassay using a commercially available kit (Meso Scale Discovery, Gaithersburg, MD, USA).

\section{Statistical analyses}

Results are expressed as mean \pm S.E.M. and data compared using ANOVA, followed by a Student-Newman-Keuls post hoc test. Incremental areas under plasma glucose and insulin curves (AUC) were calculated using a computergenerated program (Prism 5, San Diego, CA, USA)
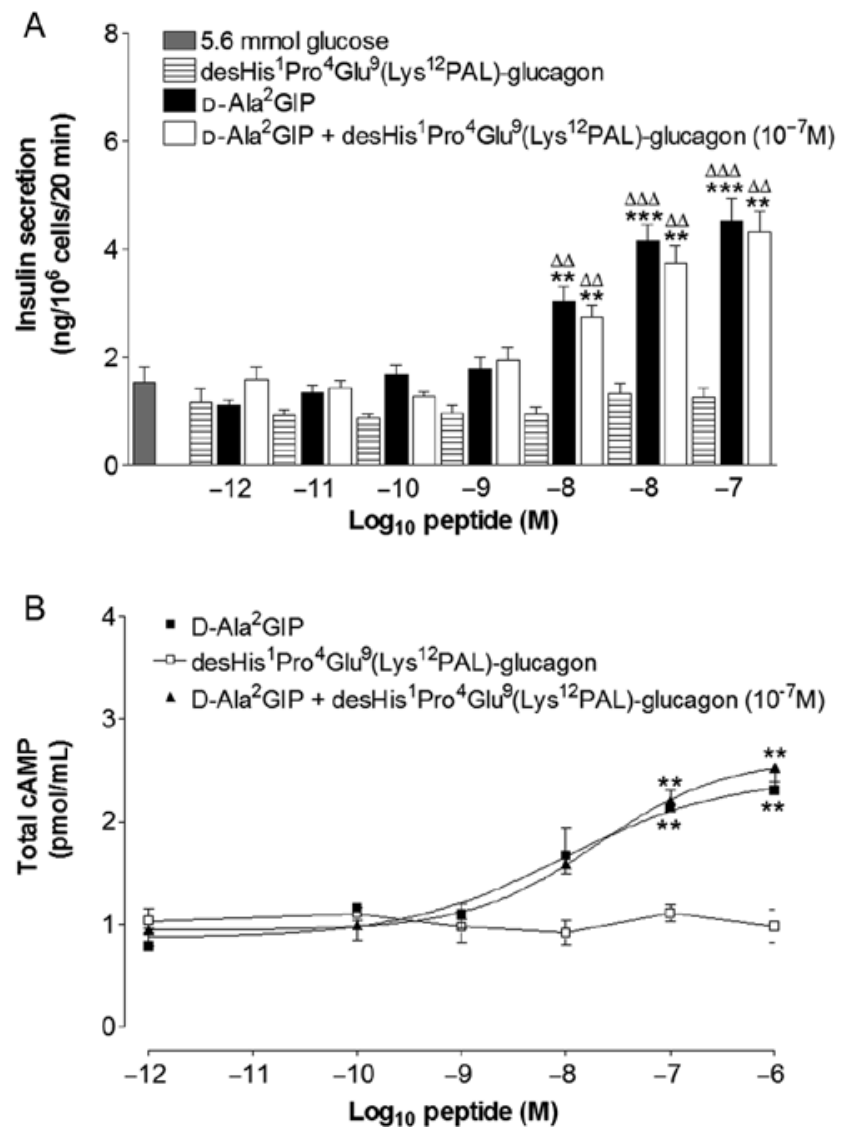

Figure 2

Insulinotropic- and CAMP-generating effects of desHis ${ }^{1} \mathrm{Pro}^{4} \mathrm{Glu}^{9}\left(\mathrm{Lys}^{12 \mathrm{PAL}}\right)$ glucagon and D-Ala 2 GIP. (A) BRIN-BD11 cells were exposed to varying concentrations $\left(10^{-12}\right.$ to $10^{-6} \mathrm{M}$ ) of des $\mathrm{His}^{1} \mathrm{Pro}^{4} \mathrm{Glu}^{9}\left(\mathrm{Lys}^{12} \mathrm{PAL}\right)$-glucagon, D-Ala ${ }^{2} \mathrm{GIP}$, and D-Ala ${ }^{2} \mathrm{GIP}$ in the presence of $10^{-7} \mathrm{M}$ desHis ${ }^{1} \mathrm{Pro}^{4} \mathrm{Glu}^{9}$ (Lys ${ }^{12} \mathrm{PAL}$ )-glucagon for $20 \mathrm{~min}$ at $5.6 \mathrm{mmol}$ glucose. (A) Extracellular insulin secretion was measured by RIA and (B) total CAMP generation measured by ELISA. Values represent mean \pm S.E.M. $(n=8)$, where $* * P<0.01, * * * P<0.001$ compared with $5.6 \mathrm{mmol}$ glucose control. $\Delta \Delta P<0.01, \Delta \Delta \Delta P<0.001$ compared with desHis ${ }^{1}$ Pro $^{4} \mathrm{Glu}^{9}\left(\mathrm{Lys}^{12} \mathrm{PAL}\right)$ glucagon alone.

Published by Bioscientifica Ltd 
A
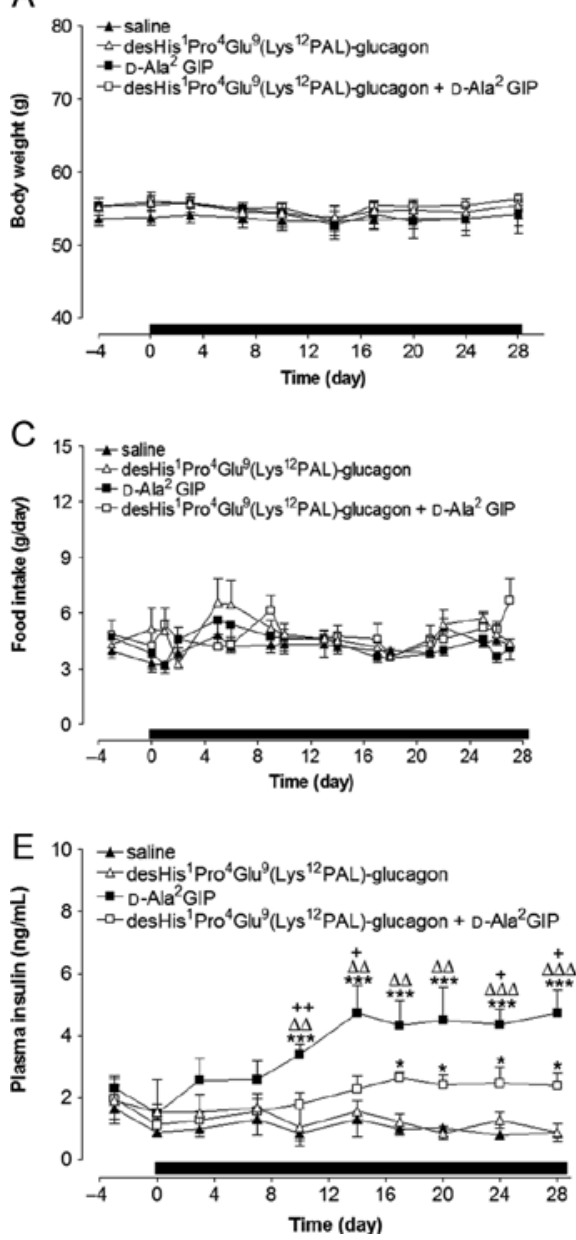

B
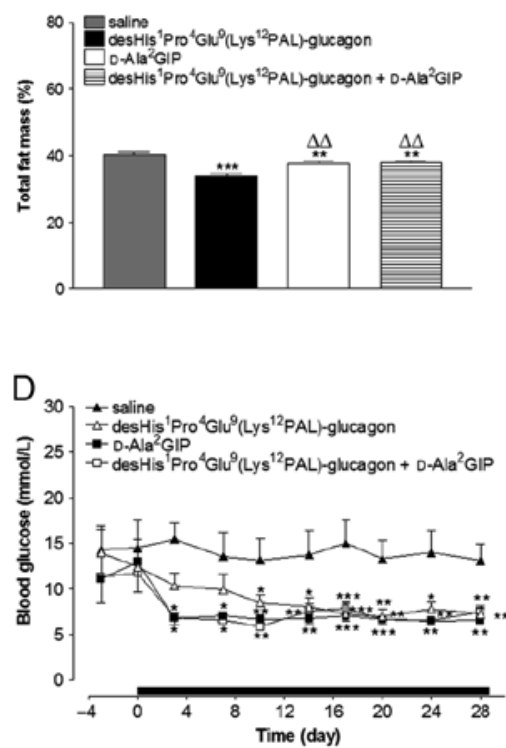

$\mathrm{F}$

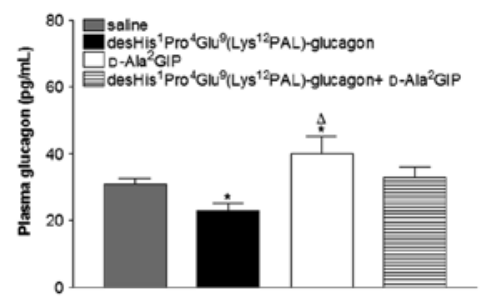

Figure 3

Effects of twice-daily treatment with desHis' ${ }^{1}$ ro $^{4} \mathrm{Glu}^{9}$ (Lys ${ }^{12} \mathrm{PAL}$ )-glucagon and $\mathrm{D}-\mathrm{Ala}^{2} \mathrm{GIP}$ alone, or in combination, on body weight, fat mass, food intake, circulating blood glucose, plasma insulin, and glucagon concentrations in high-fat mice. (A, C, D and E) Parameters were measured 4 days before, and 28 days during (indicated by horizontal black bar) twice-daily treatment with saline vehicle $(0.9 \% \mathrm{w} / \mathrm{v} \mathrm{NaCl})$, desHis ${ }^{1}$ Pro $^{4} \mathrm{Glu}^{9}$ (Lys ${ }^{12} \mathrm{PAL}$ )-glucagon, D-Ala2GIP, or desHis ${ }^{1} \mathrm{Pro}^{4} \mathrm{Glu}^{9}$ (Lys ${ }^{12} \mathrm{PAL}$ )-glucagon in combination with D-Ala ${ }^{2} \mathrm{GIP}$ (all at $25 \mathrm{nmol} / \mathrm{kg} \mathrm{bw}$ ) (B and F). Total body fat mass and plasma glucagon levels were assessed on day 28 . Values are mean \pm s.E.M. for eight mice. ${ }^{*} P<0.05$, $* * P<0.01$, and $* * * P<0.001$ compared with saline group. $\Delta P<0.05, \Delta \Delta P<0.01$, and $\Delta \Delta \Delta P<0.001$ compared with desHis $\mathrm{Pro}^{4} \mathrm{Glu}^{9}\left(\mathrm{Lys}^{12} \mathrm{PAL}\right)$ glucagon treatment alone. $+P<0.05$ and $++P<0.01$ compared with the combined treatment group. employing the trapezoidal rule with baseline subtraction. $P<0.05$ was considered to be significantly different.

\section{Results}

\section{Circular dichroism analysis of peptides}

In aqueous conditions, all peptides had an overall random structure. Upon addition of TFE, two negative dichroic bands at 208 and $222 \mathrm{~nm}$ were observed indicating the formation of alpha-helical conformations within the peptide analogs. The alpha-helical content of glucagon was calculated at $26-31 \%$ at high TFE concentrations (Fig. 1A). As the concentration of TFE increased, desHis ${ }^{1} \mathrm{Pro}^{4} \mathrm{Glu}^{9}\left(\mathrm{Lys}^{12} \mathrm{PAL}\right)$ glucagon revealed an overall trend of increasing alphahelical concentration with decreased beta-sheet content (Fig. 1B). In comparison to native glucagon (Fig. 1A), desHis ${ }^{1}$ Pro $^{4} \mathrm{Glu}^{9}$ (Lys $\left.{ }^{12} \mathrm{PAL}\right)$-glucagon had increased alphahelical content at 15-70\% TFE concentrations (Fig. 1B).
Effects of desHis ${ }^{1}$ Pro $^{4} \mathrm{Glu}^{9}\left(\right.$ Lys $\left.^{12} \mathrm{PAL}\right)$-glucagon and D-Ala2 ${ }^{2}$ IP on acute insulin secretion and CAMP production in BRIN-BD11 cells

The acylated glucagon receptor antagonist, desHis ${ }^{1}$ Pro $^{4} \mathrm{Glu}^{9}$ (Lys ${ }^{12} \mathrm{PAL}$ )-glucagon, had no significant stimulatory effect on either insulin secretion (Fig. 2A) or cAMP production (Fig. 2B) in BRIN-BD11 cells. However, the stable GIP agonist, D-Ala ${ }^{2} \mathrm{GIP}$, induced a significant $(P<0.01 \quad$ to $\quad P<0.001) \quad$ concentration-dependant $\left(10^{-8}\right.$ to $\left.10^{-6} \mathrm{M}\right)$ increase in insulin secretion when compared with a $5.6 \mathrm{mmol} / \mathrm{L}$ glucose control (Fig. 2A). Coincubation of desHis ${ }^{1} \mathrm{Pro}^{4} \mathrm{Glu}^{9}\left(\mathrm{Lys}^{12} \mathrm{PAL}\right)$-glucagon $\left(10^{-7} \mathrm{M}\right)$ with $\mathrm{D}-\mathrm{Ala}{ }^{2} \mathrm{GIP}$ had no effect on D-Ala ${ }^{2} \mathrm{GIP}$ mediated insulin release (Fig. 2A). Furthermore, desHis ${ }^{1} \mathrm{Pro}^{4} \mathrm{Glu}^{9}\left(\mathrm{Lys}^{12} \mathrm{PAL}\right)$-glucagon $\left(10^{-7} \mathrm{M}\right)$ had no inhibitory effect on $\mathrm{D}-\mathrm{Ala}^{2} \mathrm{GIP}$-induced $(P<0.01)$ cAMP production (Fig. 2B).
(C) 2016 Society for Endocrinology Printed in Great Britain 
A
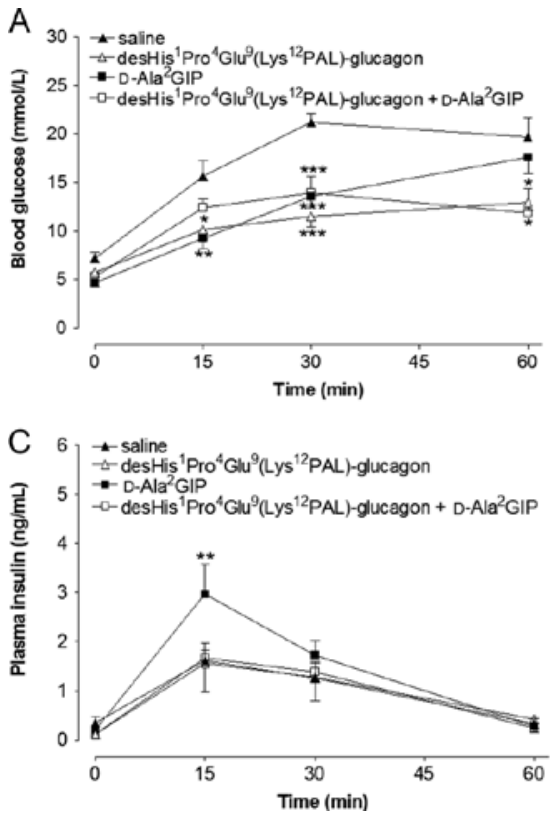

Effects of 28-days administration of desHis' ${ }^{1}$ ro $^{4} \mathrm{Glu}^{9}$ (Lys $\left.{ }^{12} \mathrm{PAL}\right)$-glucagon and D-Ala2GIP on metabolic parameters in high-fat-diet-induced obese mice

Twice-daily treatment with desHis ${ }^{1} \mathrm{Pro}^{4} \mathrm{Glu}^{9}\left(\mathrm{Lys}^{12} \mathrm{PAL}\right)$ glucagon or D-Ala ${ }^{2} \mathrm{GIP}$ alone, and in combination, for 28 days had no significant effect on body weight (Fig. 3A) or food intake (Fig. 3C). However, total body fat mass was significantly $(P<0.01$ to $P<0.001)$ reduced in all treatment groups (Fig. 3B), specifically saline control-, desHis ${ }^{1} \mathrm{Pro}^{4} \mathrm{Glu}^{9}\left(\mathrm{Lys}^{12} \mathrm{PAL}\right)$-glucagon-, and D-Ala ${ }^{2} \mathrm{GIP}-$ treated high-fat mice had body fat masses of $40.3 \pm 0.6 \%$, $33.8 \pm 0.8 \%$, and $37.7 \pm 0.5 \%$, respectively, compared with a body fat mass of $37.8 \pm 0.5 \%$ in lean control mice. In addition, D-Ala ${ }^{2}$ GIP-treated mice and those given the combination of both peptides had increased $(P<0.01)$ body fat percentage compared with desHis ${ }^{1} \mathrm{Pro}^{4} \mathrm{Glu}^{9}\left(\mathrm{Lys}^{12} \mathrm{PAL}\right)$ glucagon treatment alone (Fig. 3B). Furthermore, a significant $(P<0.05$ to $P<0.001)$ decrease in circulating blood glucose was observed in all three treatment groups from day 10 onward when compared with saline controls (Fig. 3D). In addition, D-Ala ${ }^{2}$ GIP induced a highly significant $(P<0.05$ to $P<0.001)$ increase in circulating insulin on day 28 compared with all other groups (Fig. 3E), whereas desHis ${ }^{1} \mathrm{Pro}^{4} \mathrm{Glu}^{9}\left(\mathrm{Lys}^{12} \mathrm{PAL}\right)$ glucagon monotherapy had no effect on plasma insulin levels (Fig. 3E). D-Ala ${ }^{2}$ GIP-mediated elevations in plasma insulin were partially restrained by a combined desHis ${ }^{1} \mathrm{Pro}^{4} \mathrm{Glu}^{9}\left(\mathrm{Lys}^{12} \mathrm{PAL}\right)$-glucagon therapy, although values still remained significantly $(P<0.05)$ higher

\section{Figure 4}

Effects of twice-daily treatment with desHis ${ }^{1}$ Pro $^{4} \mathrm{Glu}^{9}\left(\right.$ Lys $^{12} \mathrm{PAL}$ )-glucagon and $\mathrm{D}-\mathrm{Ala}{ }^{2} \mathrm{GIP}$ alone, or in combination, on intraperitoneal glucose tolerance and plasma insulin response to glucose in high-fat mice. Tests were conducted after 28 days twice-daily treatment with saline vehicle $(0.9 \% \mathrm{w} / \mathrm{v} \mathrm{NaCl})$, desHis ${ }^{1}$ Pro $^{4} \mathrm{Glu}^{9}$ (Lys ${ }^{12} \mathrm{PAL}$ )-glucagon, D-Ala ${ }^{2} \mathrm{GIP}$, or desHis' ${ }^{1}{ }^{1} 0^{4} \mathrm{Glu}^{9}\left(\right.$ Lys $\left.^{12} \mathrm{PAL}\right)$-glucagon in combination with D-Ala ${ }^{2} \mathrm{GIP}$ (all at $25 \mathrm{nmol} / \mathrm{kg}$ bw). (A and C) Glucose ( $18 \mathrm{mmol} / \mathrm{kg} \mathrm{bw}$ ) was administered by i.p. injection at $t=0$ in $18 \mathrm{~h}$ fasted mice. (B and $D$ ) Blood glucose and plasma insulin AUC values for 0-60 min post injection are also shown. Values are mean \pm s.E.M. for eight mice. ${ }^{*} P<0.05,{ }^{*} P<0.01$, and $* * * P<0.001$ compared with saline group. $\Delta P<0.05$ compared with desHis ${ }^{1} \mathrm{Pro}^{4} \mathrm{Glu}^{9}$ (Lys $\left.{ }^{12} \mathrm{PAL}\right)$-glucagon treatment alone. compared with desHis ${ }^{1} \mathrm{Pro}^{4} \mathrm{Glu}^{9}\left(\mathrm{Lys}^{12} \mathrm{PAL}\right)$-glucagon alone from days 17 through 28 (Fig. 3E). Circulating plasma glucagon concentrations were significantly $(P<0.01)$ elevated in $\mathrm{D}-\mathrm{Ala}^{2} \mathrm{GIP}$ mice compared with saline- and desHis ${ }^{1} \mathrm{Pro}^{4} \mathrm{Glu}^{9}\left(\mathrm{Lys}^{12} \mathrm{PAL}\right)$-glucagon-treated mice at the end of the study, whereas desHis ${ }^{1} \mathrm{Pro}^{4} \mathrm{Glu}^{9}\left(\mathrm{Lys}^{12} \mathrm{PAL}\right)$ glucagon treatment alone resulted in a significant $(P<0.05)$ reduction in glucagon concentrations (Fig. 3F). A combined administration of both peptides resulted in no significant change in plasma glucagon concentrations compared with high-fat control mice (Fig. 3F). Thus, desHis ${ }^{1} \mathrm{Pro}^{4} \mathrm{Glu}^{9}\left(\mathrm{Lys}^{12} \mathrm{PAL}\right)$-glucagon prevented the significant $(P<0.05)$ augmentation of circulating glucagon induced by $\mathrm{D}-\mathrm{Ala}^{2} \mathrm{GIP}$ treatment alone. Interestingly, the insulin:glucagon molar ratios on day 28 were 23:1, 71:1, and 44:1 in desHis ${ }^{1} \mathrm{Pro}^{4} \mathrm{Glu}^{9}\left(\mathrm{Lys}^{12} \mathrm{PAL}\right)$ glucagon, D-Ala ${ }^{2} \mathrm{GIP}$, and the combined treatment groups, respectively, compared with 17:1 in saline-treated controls.

\section{Effects of 28-days administration of} desHis ${ }^{1} \mathrm{Pro}^{4} \mathrm{Glu}^{9}$ (Lys $\left.{ }^{12} \mathrm{PAL}\right)$-glucagon and $\mathrm{D}-\mathrm{Ala}^{2} \mathrm{GIP}$ on glucose tolerance and insulin sensitivity in high-fat-diet-induced obese mice

All treatment groups had significantly $(P<0.05$ to $P<0.01)$ reduced blood glucose excursions during an i.p. glucose tolerance test when compared with saline controls (Fig. 4A and $\mathrm{B}$ ). In addition, $\mathrm{D}-\mathrm{Ala}^{2} \mathrm{GIP}$ treatment was associated with a significantly $(P<0.01)$ enhanced overall 
A
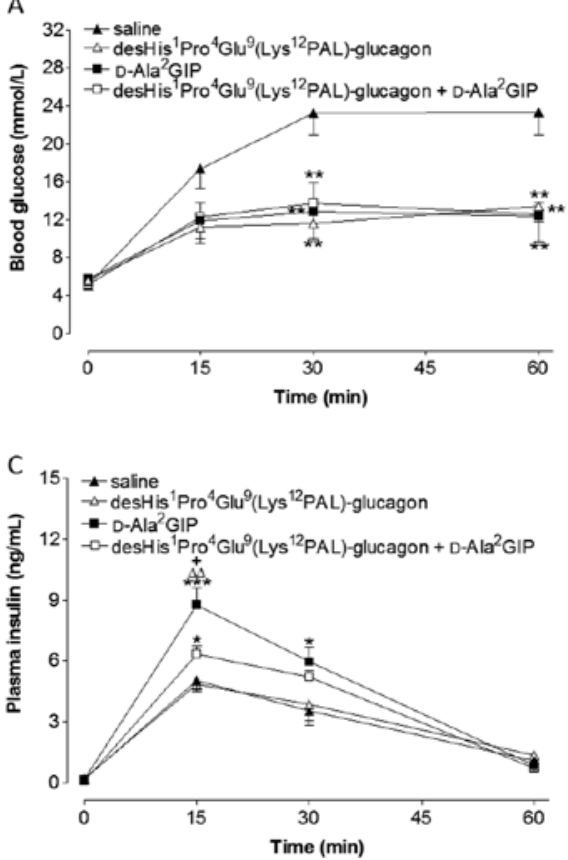

B

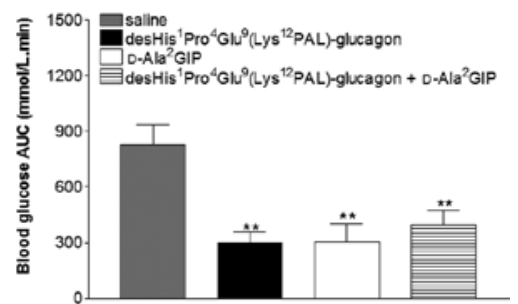

D

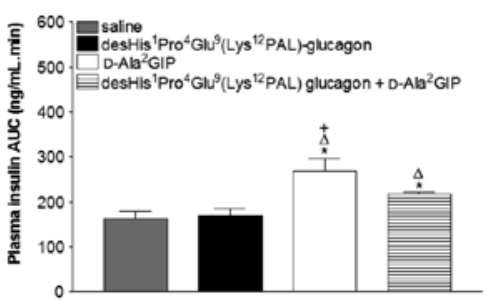

Figure 5

Effects of twice-daily treatment with desHis ${ }^{1} \mathrm{Pro}^{4} \mathrm{Glu}^{9}{ }^{9}$ Lys ${ }^{12} \mathrm{PAL}$ )-glucagon and $\mathrm{D}-\mathrm{Ala}^{2} \mathrm{GIP}$ alone, or in combination, on oral glucose tolerance and plasma insulin response to glucose in high-fat mice. Tests were conducted after 28 days twice-daily treatment with saline vehicle $(0.9 \% \mathrm{w} / \mathrm{v} \mathrm{NaCl})$, desHis ${ }^{1} \mathrm{Pro}^{4} \mathrm{Glu}^{9}$ (Lys $\left.{ }^{12} \mathrm{PAL}\right)-$ glucagon, D-Ala ${ }^{2} \mathrm{GIP}$, or desHis ${ }^{1} \mathrm{Pro}^{4} \mathrm{Glu}^{9}\left(\mathrm{Lys}^{12} \mathrm{PAL}\right.$ )glucagon in combination with $\mathrm{D}-\mathrm{Ala}^{2} \mathrm{GIP}$ (all at $25 \mathrm{nmol} / \mathrm{kg} \mathrm{bw}$ ). (A and C) Glucose ( $18 \mathrm{mmol} / \mathrm{kg}$ bw) was administered by oral gavage at $t=0$ in 18 hfasted mice. (B and D) Blood glucose and plasma insulin AUC values for $0-60$ min post injection are also shown. Values are mean \pm S.E.M. for eight mice. $* P<0.05, * * P<0.01$, and $* * * P<0.001$ compared with the saline-treated control group. $\Delta P<0.05$ and $\Delta \Delta P<0.01$ compared with desHis ${ }^{1} \mathrm{Pro}^{4} \mathrm{Glu}^{9}$ (Lys ${ }^{12} \mathrm{PAL}$ )-glucagon treatment alone. $+P<0.05$ compared with the combined treatment group. insulinotropic response in comparison with control mice (Fig. 4C and D). Similarly, during an oral glucose challenge, blood glucose levels were significantly $(P<0.01)$ reduced 30 and 60 min post administration in all treatment groups (Fig. 5A). In harmony with observations following an i.p. glucose load, D-Ala ${ }^{2}$ GIP treatment significantly enhanced the individual $(P<0.05$ to $P<0.001)$ and overall $(P<0.05)$ insulin secretory response following oral glucose delivery when compared with all other groups of mice (Fig. 5C and D). Likewise, a combined treatment of $\mathrm{D}-\mathrm{Ala}^{2} \mathrm{GIP}$ with desHis ${ }^{1}$ Pro $^{4} \mathrm{Glu}^{9}$ (Lys ${ }^{12} \mathrm{PAL}$ )-glucagon also enhanced $(P<0.05)$ the overall insulin secretory response (Fig. 5C and D). As shown in Fig. 6, treatment with D-Ala ${ }^{2}$ GIP alone, or in combination with desHis ${ }^{1} \mathrm{Pro}^{4} \mathrm{Glu}^{9}\left(\mathrm{Lys}^{12} \mathrm{PAL}\right)-$ glucagon, significantly $(P<0.01)$ improved the glucoselowering action of exogenous insulin at 30 and $60 \mathrm{~min}$ post insulin injection when compared with saline controls (Fig. 6A). Treatment with desHis ${ }^{1} \mathrm{Pro}^{4} \mathrm{Glu}^{9}\left(\mathrm{Lys}^{12} \mathrm{PAL}\right)-$ glucagon alone also resulted in a significant $(P<0.01)$ reduction in blood glucose levels at $60 \mathrm{~min}$ post insulin injection (Fig. 6A). Moreover, the overall glucose-lowering effect of insulin was significantly $(P<0.05$ to $P<0.01)$ enhanced in all treatment groups (Fig. 6B). Interestingly, pancreatic insulin content was significantly $(P<0.05$ to $P<0.01)$ higher in mice treated with $\mathrm{D}$-Ala ${ }^{2} \mathrm{GIP}$ alone, or in combination with desHis ${ }^{1} \mathrm{Pro}^{4} \mathrm{Glu}^{9}\left(\mathrm{Lys}^{12} \mathrm{PAL}\right)$ glucagon, when compared with saline controls or desHis ${ }^{1} \mathrm{Pro}^{4} \mathrm{Glu}^{9}\left(\mathrm{Lys}^{12} \mathrm{PAL}\right)$-glucagon treatment alone (Fig. 6C).

\section{Effects of 28-days administration of desHis ${ }^{1}$ Pro $^{4} \mathrm{Glu}^{9}$ (Lys $\left.{ }^{12} \mathrm{PAL}\right)$-glucagon and D-Ala²GIP on metabolic rate and locomotor activity in high-fat-diet-induced obese mice}

Treatment with desHis ${ }^{1} \mathrm{Pro}^{4} \mathrm{Glu}^{9}\left(\mathrm{Lys}^{12} \mathrm{PAL}\right)$-glucagon alone, and in combination with D-Ala ${ }^{2} \mathrm{GIP}$, significantly $(P<0.001)$ increased energy expenditure during the dark phase compared with saline-treated controls and D-Ala ${ }^{2} \mathrm{GIP}$ treatment alone (Fig. 7A). Respiratory exchange ratio was not different between groups of mice (Fig. 7B). Ambulation, as assessed by $\mathrm{X}$-beam breaks, was significantly $(P<0.05)$ elevated in mice treated with desHis ${ }^{1} \mathrm{Pro}^{4} \mathrm{Glu}^{9}\left(\mathrm{Lys}^{12} \mathrm{PAL}\right)$ glucagon alone, or in combination with D-Ala ${ }^{2} \mathrm{GIP}$ (Fig. 7C). D-Ala ${ }^{2}$ GIP treatment did not affect X-beam breaks when compared with control mice (Fig. 7C). All three treatment groups had significantly $(P<0.05$ to $P<0.001)$ increased numbers of Z-beam breaks compared with controls, with the combination treatment group also displaying increased Z-beam breaks when compared with individual treatment regimens (Fig. 7D). Energy expenditure, ambulatory activity, and Z-beam breaks were not significantly different between groups during the light phase (data not shown).

\section{Discussion}

Notwithstanding encouraging preclinical data (Bagger et al. 2011, Trujillo \& Nuffer 2014), the progression

Published by Bioscientifica Ltd 
A
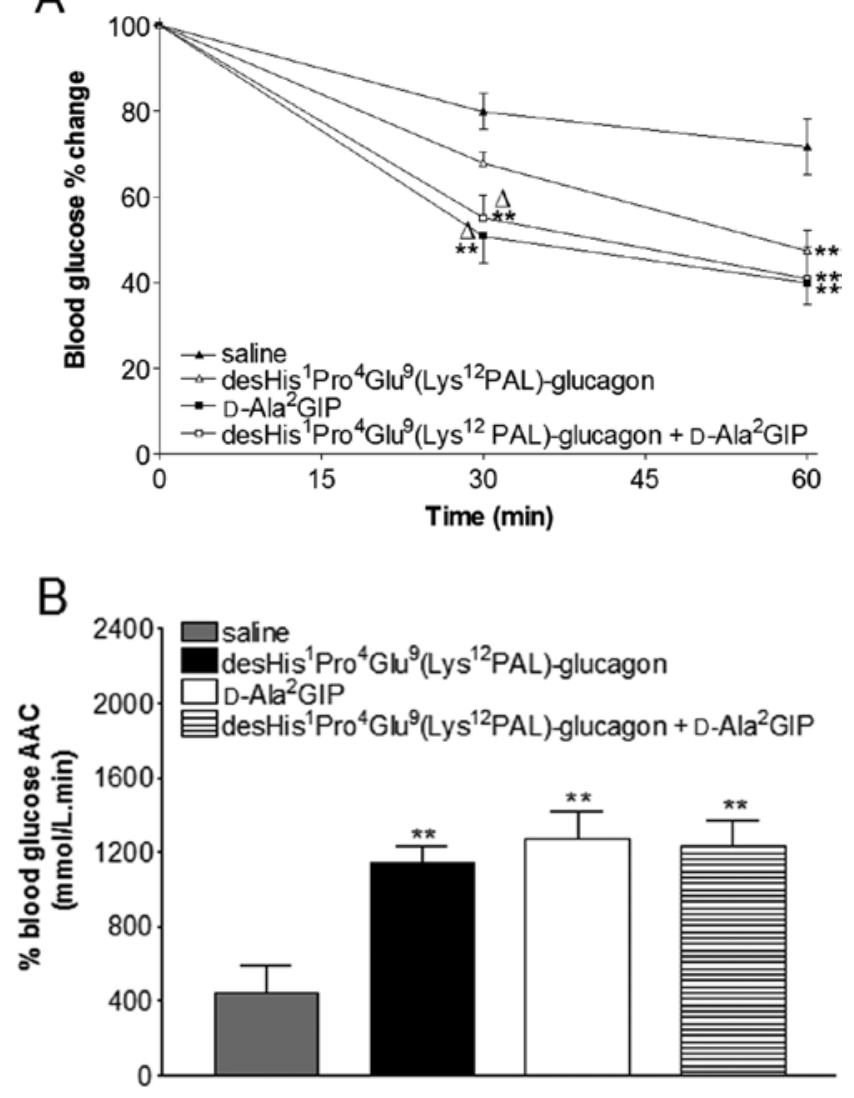

C

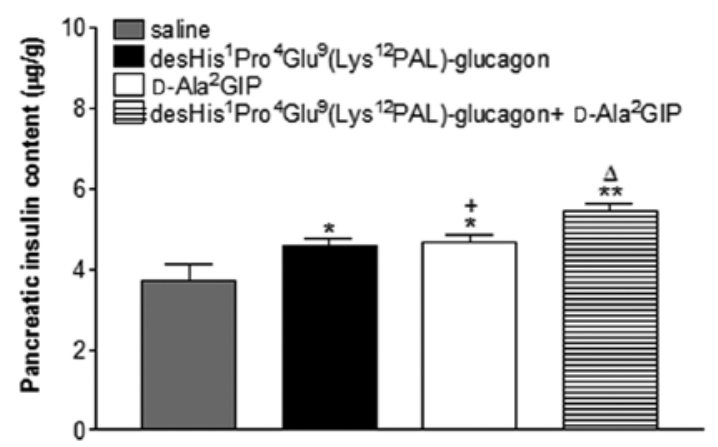

Figure 6

Effects of twice-daily treatment with desHis ${ }^{1} \mathrm{Pro}^{4} \mathrm{Glu}^{9}$ (Lys $\left.{ }^{12} \mathrm{PAL}\right)$-glucagon and D-Ala2GIP alone, or in combination, on peripheral insulin sensitivity and pancreatic insulin content in high-fat mice. Tests were conducted after 28 days twice-daily treatment with saline vehicle $(0.9 \% \mathrm{w} / \mathrm{v} \mathrm{NaCl})$, desHis ${ }^{1} \mathrm{Pro}^{4} \mathrm{Glu}^{9}$ (Lys ${ }^{12} \mathrm{PAL}$ )-glucagon, D-Ala ${ }^{2} \mathrm{GIP}$, or desHis ${ }^{1} \mathrm{Pro}^{4} \mathrm{Glu}^{9}$ (Lys ${ }^{12} \mathrm{PAL}$ )-glucagon in combination with D-Ala2GIP (all at $25 \mathrm{nmol} / \mathrm{kg} \mathrm{bw}$ ). (A) Insulin (10 U/kg bw) was administered by i.p. injection at $t=0$ in nonfasted mice. (B) Blood glucose AAC values for 0-60 min post injection are also shown, where the baseline is $100 \%$. (C) Pancreatic insulin content was assessed on day 28 following acid-ethanol extraction and measurement of insulin concentrations by RIA. Values are mean \pm S.E.M. for eight mice. ${ }^{*} P<0.05$ and $* * P<0.01$ compared with saline-treated control group. $\triangle P<0.05$ compared with desHis ${ }^{1} \mathrm{Pro}^{4} \mathrm{Glu}^{9}\left(\mathrm{Lys}^{12} \mathrm{PAL}\right)$-glucagon treatment alone. $+P<0.05$ compared with the combined treatment group. of monotherapy glucagon antagonist- or GIP agonistbased therapies to the clinic is lacking. This is despite knowledge that a potential major beneficial effect of the most widely used antidiabetic drug, metformin, is mediated through inhibition of glucagon action (Pernicova \& Korbonits 2014). Furthermore, recent studies have shown that targeting multiple regulatory hormone receptors may be a viable treatment option for T2DM (Patel et al. 2013, Trevaskis et al. 2013, Skarbaliene et al. 2015). As such, the dual activation of incretin-related pathways coupled with glucagon receptor blockade significantly improves metabolic control in diabetes (Claus et al. 2007, Mu et al. 2011). Given that a documented therapeutic drawback of GIP mimetics relates to elevation of glucagon levels (Meier \& Nauck 2004, 2015), a combined therapy with a specific glucagon antagonist would seem logical. Here, we assessed the benefits of combining the glucagon receptor antagonist, desHis ${ }^{1} \mathrm{Pro}^{4} \mathrm{Glu}^{9}\left(\mathrm{Lys}^{12} \mathrm{PAL}\right)$-glucagon (O'Harte et al. 2014), with the well characterized DPP4-resistant GIP analog, D-Ala ${ }^{2}$ GIP (Hinke et al. 2002, Widenmaier et al. 2010). We aimed to prove the concept that desHis ${ }^{1} \mathrm{Pro}^{4} \mathrm{Glu}^{9}\left(\mathrm{Lys}^{12} \mathrm{PAL}\right)$-glucagon could counter GIP-related elevations of blood glucagon levels.

Structure function studies with native glucagon have shown that the C-terminal portion of peptide, which exhibits an alpha-helical conformation, is involved in receptor recognition, with the N-terminal more important for receptor signaling (Sturm et al. 1998). In this study, desHis ${ }^{1} \mathrm{Pro}^{4} \mathrm{Glu}^{9}\left(\mathrm{Lys}^{12} \mathrm{PAL}\right)$-glucagon had an increased $\alpha$-helical content when compared with native glucagon, a trait that is strongly associated with increased receptorbinding potency (Krstenansky et al. 1988). As previously shown by the leading synthetic peptide groups of Hruby and Merrifield, and later independently confirmed in our laboratory, His ${ }^{1}$, Gly ${ }^{4}$, and $\mathrm{Asp}^{9}$ are essential for normal agonist activity of glucagon at the level of the receptor (Hruby 1982, Unson et al. 1991, 1993, Ahn et al. 2001, O'Harte et al. 2013, Franklin et al. 2014, McShane et al. 2014). In complete harmony with this structural data, desHis ${ }^{1} \mathrm{Pro}^{4} \mathrm{Glu}^{9}\left(\mathrm{Lys}^{12} \mathrm{PAL}\right)$-glucagon is known to inhibit glucagon-induced elevations of cAMP generation and insulin secretion (O'Harte et al. 2013). Both the glucagon and GIP receptors belong to the same family of G-proteincoupled receptors (Brubaker \& Drucker 2002) and share considerable structural homology (Kogire et al. 1992). However, desHis ${ }^{1} \mathrm{Pro}^{4} \mathrm{Glu}^{9}\left(\mathrm{Lys}^{12} \mathrm{PAL}\right)$-glucagon did not adversely hinder the insulinotropic and cAMP potentiating effect of $\mathrm{D}^{-\mathrm{Ala}^{2} \mathrm{GIP}}$ (Martin et al. 2013), further confirming specificity.

Published by Bioscientifica Ltd 
A

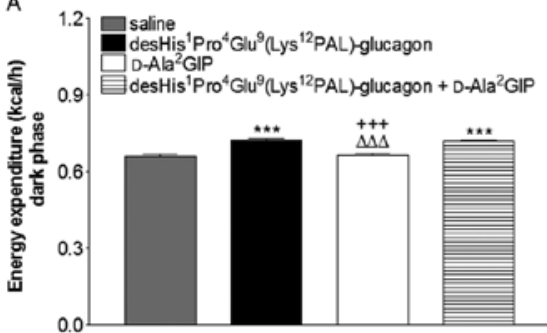

c

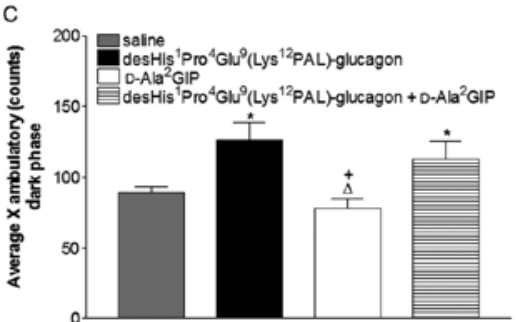

B
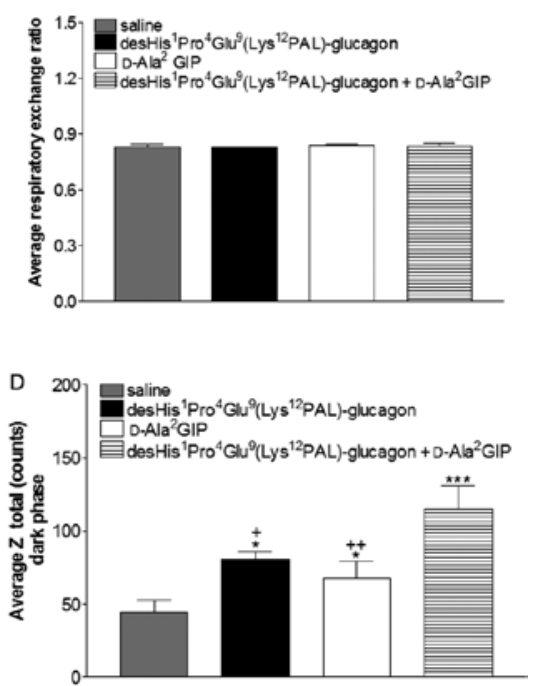

Figure 7

Effects of twice-daily treatment with

desHis ${ }^{1} \mathrm{Pro}^{4} \mathrm{Glu}^{9}{ }^{(}$Lys $^{12} \mathrm{PAL}$ )-glucagon and D-Ala ${ }^{2} \mathrm{GIP}$ alone, or in combination, on metabolic rate and locomotor activity in high-fat mice. Parameters were measured after 28 days twice-daily treatment with saline vehicle $(0.9 \% \mathrm{w} / \mathrm{v} \mathrm{NaCl})$, desHis ${ }^{1} \mathrm{Pro}^{4} \mathrm{Glu}^{9}$ (Lys ${ }^{12} \mathrm{PAL}$ )-glucagon, D-Ala ${ }^{2} \mathrm{GIP}$, or desHis ${ }^{1} \mathrm{Pro}^{4} \mathrm{Glu}^{9}$ (Lys ${ }^{12} \mathrm{PAL}$ )-glucagon in combination with D-Ala ${ }^{2}$ GIP (all at $25 \mathrm{nmol} / \mathrm{kg}$ bw). (A) Energy expenditure, (B) respiratory exchange ratio, (C) ambulatory $X$ counts, and (D) total $Z$ counts were assessed by CLAMS. Values are mean \pm S.E.M. for six mice. $* P<0.05$ and $* * * P<0.001$ compared with saline group. $\Delta P<0.05$ and $\Delta \Delta \Delta P<0.001$ compared with desHis ${ }^{1} \mathrm{Pro}^{4} \mathrm{Glu}^{9}$ (Lys $12 \mathrm{PAL}$ )-glucagon treatment alone. ${ }^{+} P<0.05,{ }^{++} P<0.01$, and ${ }^{+++} P<0.001$ compared with the combined treatment group.
As would be expected, twice-daily treatment with either desHis ${ }^{1}$ Pro $^{4} \mathrm{Glu}^{9}$ (Lys $\left.{ }^{12} \mathrm{PAL}\right)$-glucagon or $\mathrm{D}-\mathrm{Ala}^{2} \mathrm{GIP}$ in high-fat-fed mice reproduced many of the beneficial effects previously noted with sustained GIP receptor activation (Kerr et al. 2009, Porter et al. 2011) or glucagon receptor blockade (Lotfy et al. 2014, McShane et al. 2014, O'Harte et al. 2014). This included significant reductions in circulating blood glucose levels and improvements in peripheral glucose disposal. Beneficial effects of both treatment regimens were independent of alterations in body weight or energy intake. Previous studies have indicated that glucagon can decrease food intake (Habegger et al. 2010, Kosinski et al. 2012); however, our studies with peptide-based glucagon antagonists suggest that contrasting elevations of energy intake do not occur with glucagon receptor inhibition (Franklin et al. 2014, McShane et al. 2014, O'Harte et al. 2014). This probably reflects the complex neural pathways and plasticity involved in the regulation of feeding and energy balance (Dockray \& Burdyga 2011). A combined therapy with desHis ${ }^{1} \mathrm{Pro}^{4} \mathrm{Glu}^{9}\left(\mathrm{Lys}^{12} \mathrm{PAL}\right)$-glucagon and D-Ala ${ }^{2}$ GIP did not result in discernible benefits on blood glucose or glucose disposal when compared with either treatment alone. This likely reflects the good efficacy of each treatment alone and the relatively high doses employed, which could preclude additive action. Indeed, circulating blood glucose levels were around $5-6 \mathrm{mmol} / \mathrm{L}$ in each treatment group by the end of the study. As has been proposed, circulating glucagon levels were

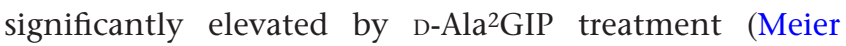
\& Nauck 2004, 2015), but this detrimental effect was completely annulled by concurrent administration of
desHis ${ }^{1}$ Pro $^{4} \mathrm{Glu}^{9}\left(\right.$ Lys $\left.^{12} \mathrm{PAL}\right)$-glucagon. Moreover, circulating insulin concentrations were reduced in mice treated with a combination of desHis ${ }^{1} \mathrm{Pro}^{4} \mathrm{Glu}^{9}\left(\mathrm{Lys}^{12 \mathrm{PAL}}\right)$ glucagon and D-Ala ${ }^{2}$ GIP, when compared with D-Ala ${ }^{2}$ GIP alone, implying improved insulin action in these mice, since ambient glucose levels were essentially similar. Indeed, pancreatic insulin stores and the insulin:glucagon ratio were substantially augmented by dual therapy on day 28 when compared with desHis ${ }^{1}$ Pro $^{4} \mathrm{Glu}^{9}\left(\mathrm{Lys}^{12} \mathrm{PAL}\right)$ glucagon treatment alone, which also points toward decreased insulin demand in the combined treatment group. Plasma glucagon levels were actually reduced by desHis ${ }^{1} \mathrm{Pro}^{4} \mathrm{Glu}^{9}$ (Lys $\left.{ }^{12} \mathrm{PAL}\right)$-glucagon monotherapy, which is somewhat unexpected given previous observations (Bagger et al. 2011), and, therefore, does require further investigation.

Interestingly, total body fat mass was lowered in all treatment groups without change in overall body weight, suggesting a possible shift toward the use of stored fat as an energy source. Somewhat surprisingly, although in agreement with increased fat utilization, energy expenditure was increased during the dark phase in all mice receiving desHis ${ }^{1} \mathrm{Pro}^{4} \mathrm{Glu}^{9}\left(\mathrm{Lys}^{12} \mathrm{PAL}\right)$-glucagon treatment. Thus, glucagon receptor activation is generally associated with enhanced energy expenditure (Campbell \& Drucker 2015) implying that counter-regulatory mechanisms may be important for the benefits of sustained glucagon receptor inhibition in this study. However, respiratory exchange ratio was unaltered between groups with values of approximately 0.85 , indicating a similar combination of fat and carbohydrates utilization. Interestingly, mice with genetic knock out of synaptotagmin-7, a regulator of glucagon and insulin secretion, present with reduced 
circulating glucagon levels and increased energy expenditure (Lou et al. 2011), in harmony with the current findings. Ambulatory locomotion was also elevated only in mice where glucagon receptor action was inhibited. The overall significance of these centrally mediated effects requires further detailed elucidation. Moreover, the passage of both desHis ${ }^{1} \mathrm{Pro}^{4} \mathrm{Glu}^{9}\left(\mathrm{Lys}^{12 \mathrm{PAL}}\right)$-glucagon and $\mathrm{D}-\mathrm{Ala}^{2} \mathrm{GIP}$ through the blood-brain barrier also requires investigation.

Improvements in glucose tolerance and glucosestimulated insulin release are a previously reported feature of $\mathrm{D}$-Ala ${ }^{2} \mathrm{GIP}$ treatment in high-fat-fed mice (Gault et al. 2011). Indeed, studies suggest that high-fat feeding increases islet GIP receptor expression (Harada et al. 2008, Moffett et al. 2015). Thus, the GIP analog may be able to independently overcome any potential GIP resistance (Nauck et al. 1993) in this mouse model of T2DM. Similarly, improvements in response to both oral and intraperitoneal glucose challenge were observed in desHis ${ }^{1} \mathrm{Pro}^{4} \mathrm{Glu}^{9}\left(\mathrm{Lys}^{12} \mathrm{PAL}\right)$-glucagon mice, consistent with previous studies (O'Harte et al. 2013). This was despite any obvious increase in glucose-stimulated insulin secretion in desHis ${ }^{1} \mathrm{Pro}^{4} \mathrm{Glu}^{9}\left(\mathrm{Lys}^{12 \mathrm{PAL}}\right)$-glucagon treated mice. In agreement with this, peripheral insulin sensitivity was dramatically improved by desHis ${ }^{1}$ Pro $^{4} \mathrm{Glu}^{9}$ (Lys ${ }^{12} \mathrm{PAL}$ )-glucagon; however, this was also the case for all treatment paradigms. Thus, improved insulin action might simply be a reflection of decreased glucose toxicity in each treatment group, due to lower circulating blood glucose concentrations. This might also be a reason for the lack of benefit of the combined treatment regimen. More interestingly, D-Ala ${ }^{2} \mathrm{GIP}$-induced elevations of insulin secretion appeared to be blunted by the coadministration of $\operatorname{desHis}^{1} \mathrm{Pro}^{4} \mathrm{Glu}^{9}\left(\mathrm{Lys}^{12} \mathrm{PAL}\right)$ glucagon following intraperitoneal glucose, but much less so following oral glucose administration. This would suggest $\mathrm{D}$-Ala ${ }^{2} \mathrm{GIP}$ treatment alone, and in combination

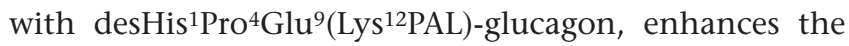
incretin axis in high-fat-fed mice (Moffett et al. 2015). Indeed, this could be linked to augmented secretion and/ or action of GLP-1 following an oral glucose challenge in these mice, as suggested previously (Parker et al. 2002, Gelling et al. 2003).

In conclusion, this study indicates that twice-daily injection of either $\mathrm{D}-\mathrm{Ala}^{2} \mathrm{GIP}$ or desHis ${ }^{1} \mathrm{PrO}^{4} \mathrm{Glu}^{9}\left(\mathrm{Lys}^{12} \mathrm{PAL}\right)$ glucagon is an effective means of improving diabetic control in obese-diabetic high-fat-fed mice. There was some limited evidence for benefits following combined treatment, but this requires further detailed study to assess the relative importance. As such, studies utilizing various concentration and ratios of individual peptides could be interesting and might reveal further benefits. Importantly, however, a combined therapy of desHis ${ }^{1}$ Pro $^{4} \mathrm{Glu}^{9}$ (Lys $\left.{ }^{12} \mathrm{PAL}\right)$-glucagon with $\mathrm{D}-\mathrm{Ala}{ }^{2} \mathrm{GIP}$ did completely annul GIP-induced elevations of circulating glucagon levels and augment pancreatic insulin stores, confirming proof of concept. Furthermore, it may be interesting to examine the metabolic benefits of sustained glucagon inhibition in combination with GLP-1 receptor activation, or in other animal models of diabetes. Taken together, the data presented here provide evidence for the usefulness of peptide-based GIP receptor agonist and glucagon receptor antagonist therapies for the treatment of T2DM.

\section{Declaration of interest}

The authors declare that there is no conflict of interest that could be perceived as prejudicing the impartiality of the research reported.

\section{Funding}

This work was supported by an Invest Northern Ireland, POC106 grant and a DEL NI PhD Studentship.

\section{Author contribution statement}

$\mathrm{L}$ MCS, D O F, and $\mathrm{Z} J \mathrm{~F}$ were involved in performing this research for cell work, in vivo work in mice, and $\mathrm{CD}$ analysis. $\mathrm{CMH}$ was involved in $\mathrm{CD}$ work and supervision. $\mathrm{L} \mathrm{MCS,} \mathrm{N} \mathrm{I,} \mathrm{and} \mathrm{FOH}$ were involved in the preparation of data, writing up this work, and proofreading the document.

\section{References}

Ahn JM, Medeiros M, Trivedi D \& Hruby VJ 2001 Development of potent glucagon antagonists: structure-activity relationship study of glycine at position 4. Journal of Peptide Research 58 151-158. (doi:10.1034/ j.1399-3011.2001.00880.x)

Bagger JI, Knop FK, Holst JJ \& Vilsbøll T 2011 Glucagon antagonism as a potential therapeutic target in type 2 diabetes. Diabetes, Obesity \& Metabolism 13 965-971.

Brubaker PL \& Drucker DJ 2002 Structure-function of the glucagon receptor family of $\mathrm{G}$ protein-coupled receptors: the glucagon, GIP, GLP-1, and GLP-2 receptors. Receptors \& Channels 8 179-188.

Campbell JE \& Drucker DJ 2015 Islet $\alpha$ cells and glucagon - critical regulators of energy homeostasis. Nature Reviews. Endocrinology 11 329-338. (doi:10.1038/nrendo.2015.51)

Chaplin S \& Joseph F 2014 Lixisenatide (Lyxumia): new GLP-1 mimetic for type 2 diabetes. Prescriber 25 14-16. (doi:10.1002/psb.1177)

Claus TH, Pan CQ, Buxton JM, Yang L, Reynolds JC, Barucci N, Burns M, Ortiz AA, Roczniak S, Livingston JN, et al. 2007 Dual-acting peptide with prolonged glucagon-like peptide- 1 receptor agonist and glucagon receptor antagonist activity for the treatment of type 2 diabetes. Journal of Endocrinology 192 371-380. (doi:10.1677/JOE-06-0018)

Dockray GJ \& Burdyga G 2011 Plasticity in vagal afferent neurones during feeding and fasting: mechanisms and significance. Acta Physiologica 201 313-321. (doi:10.1111/j.1748-1716.2010.02219.x)

Published by Bioscientifica Ltd. 
Flatt PR \& Bailey CJ 1981 Abnormal plasma glucose and insulin responses in heterozygous lean (ob/+) mice. Diabetologia 20 573-577.

Franklin ZJ, O'Harte FPM \& Irwin N 2014 Effects of short-term chemical ablation of glucagon signaling by peptide-based glucagon receptor antagonists on insulin secretion and glucose homeostasis in mice. Biological Chemistry 395 433-442. (doi:10.1515/hsz-2013-0224)

Gault VA, Flatt PR \& O'Harte FPM 2003 Glucose-dependent insulinotropic polypeptide analogues and their therapeutic potential for the treatment of obesity-diabetes. Biochemical \& Biophysical Research Communications 308 207-213.

Gault VA, Porter DW, Irwin N \& Flatt PR 2011 Comparison of subchronic metabolic effects of stable forms of naturally occurring GIP(1-30) and GIP(1-42) in high-fat fed mice. Journal of Endocrinology 208 265-271. (doi:10.1530/JOE-10-0419)

Gelling RW, Du XQ, Dichmann DS, Romer J, Huang H, Cui L, Obici S, Tang B, Holst JJ, Fledelius C, et al. 2003 Lower blood glucose, hyperglucagonemia, and pancreatic alpha cell hyperplasia in glucagon receptor knockout mice. PNAS 100 1438-1443. (doi:10.1073/pnas.0237106100)

Gupta V 2013 Glucagon-like peptide-1 analogues: an overview. Indian Journal of Endocrinology \& Metabolism 17 413-421. (doi:10.4103/22308210.111625)

Habegger KM, Heppner KM, Geary N, Bartness TJ, DiMarchi R \& Tschöp MH 2010 The metabolic actions of glucagon revisited. Nature Reviews, Endocrinology 6 689-697. (doi:10.1038/nrendo.2010.187)

Harada N, Yamada Y, Tsukiyama K, Yamada C, Nakamura Y, Mukai E, Hamasaki A, Liu X, Toyoda K, Seino Y \& Inagaki N 2008 A novel GIP receptor splice variant influences GIP sensitivity of pancreatic betacells in obese mice. American Journal of Physiology: Endocrinology \& Metabolism 294 61-68. (doi:10.1152/ajpendo.00358.2007)

Hinke SA, Gelling RW, Pederson RA, Manhart S, Nian C, Demuth HU \& McIntosh CH 2002 Dipeptidyl peptidase IV-resistant [D-Ala(2)] glucose-dependent insulinotropic polypeptide (GIP) improves glucose tolerance in normal and obese diabetic rats. Diabetes 51 652-661. (doi:10.2337/diabetes.51.3.652)

Højberg PV, Vilsbøll T, Rabøl R, Knop FK, Bache M, Krarup T, Holst JJ \& Madsbad S 2009 Four weeks of near-normalization of blood glucose improves the insulin response to glucagon-like peptide- 1 and glucose-dependent insulinotropic polypeptide in patients with type 2 diabetes. Diabetologia 52 199-207. (doi:10.1007/s00125-008-1195-5)

Hruby VJ 1982 Structure-conformation-activity studies of glucagon and semi-synthetic glucagon analogs. Molecular and Cellular Biochemistry 44 49-64. (doi:10.1007/BF00573846)

Kelly RP, Garhyan P, Raddad E, Fu H, Lim CN, Prince MJ, Pinaire JA, Loh MT \& Deeg MA 2015 Short-term administration of the glucagon receptor antagonist LY2409021 lowers blood glucose in healthy people and in those with type 2 diabetes. Diabetes, Obesity \& Metabolism 17 414-242. (doi:10.1111/dom.12446)

Kerr BD, Irwin N, Flatt PR \& Gault VA 2009 Prolonged GIP receptor activation using stable mini-PEGylated GIP improves glucose homeostasis and beta-cell function in age-related glucose intolerance. Peptides 30 219-225. (doi:10.1016/j.peptides.2008.10.017)

Kogire M, Inoue K, Sumi S, Doi R, Yun M, Kaji H \& Tobe T 1992 Effects of gastric inhibitory polypeptide and glucagon on portal venous and hepatic arterial flow in conscious dogs. Digestive Diseases and Sciences 37 1666-1670. (doi:10.1007/BF01299856)

Kosinski JR, Hubert J, Carrington PE, Chicchi GG, Mu J, Miller C, Cao J, Bianchi E, Pessi A, Sinharoy R, et al. A 2012 The glucagon receptor is involved in mediating the body weight-lowering effects of oxyntomodulin. Obesity 20 1566-1571. (doi:10.1038/oby.2012.67)

Krstenansky JL, Zechel C, Trivedi D \& Hruby VJ 1988 Importance of the C-terminal alpha-helical structure for glucagon's biological activity. International Journal of Peptide and Protein Research 32 468-475. (doi:10.1111/j.1399-3011.1988.tb01377.x)
Lefèbvre PJ, Paquot N \& Scheen AJ 2015 Inhibiting or antagonizing glucagon: making progress in diabetes care. Diabetes, Obesity \& Metabolism 17 720-725. (doi:10.1111/dom.12480)

Lotfy M, Kalasz H, Szalai G, Singh J \& Adeghate E 2014 Recent progress in the use of glucagon and glucagon receptor antagonists in the treatment of diabetes mellitus. Open Medicinal Chemistry Journal 31 28-35. (doi:10.2174/1874104501408010028)

Lou PH, Gustavsson N, Wang Y, Radda GK \& Han W 2011 Increased lipolysis and energy expenditure in a mouse model with severely impaired glucagon secretion. PLOS ONE 6 26671-26680. (doi:10.1371/ journal.pone.0026671)

Louis-Jeune C, Andrade-Navarro MA \& Perez-Iratxeta C 2012 Prediction of protein secondary structure from circular dichroism using theoretically derived spectra. Proteins 80 374-381. (doi:10.1002/prot.24168)

Martin CM, Irwin N, Flatt PR \& Gault VA 2013 A novel acylated form of (d-Ala ${ }^{2}$ GIP with improved antidiabetic potential, lacking effect on body fat stores Biochimica et Biophysica Acta 1830 3407-3413. (doi:10.1016/j.bbagen.2013.03.011)

Meneilly GS, Bryer-Ash M \& Elahi D 2003 The effect of glyburide on beta-cell sensitivity to glucose-dependent insulinotropic polypeptide Diabetes Care 16 110-114. (doi:10.2337/diacare.16.1.110)

McShane LM, Franklin ZF, O'Harte FPM \& Irwin N 2014 Ablation of glucagon receptor signaling by peptide-based glucagon antagonists improves glucose tolerance in high fat fed mice. Peptides 60 95-101. (doi:10.1016/j.peptides.2014.08.002)

Meier JJ \& Nauck MA 2004 Clinical endocrinology gand metabolism. Glucose-dependent insulinotropic polypeptide/gastric inhibitory polypeptide. Best Practice \& Research Clinical Endocrinology \& Metabolism. 18 587-606. (doi:10.1016/j.beem.2004.08.007)

Meier JJ \& Nauck MA 2015 Incretin-based therapies: where will we be 50 years from now? Diabetologia 58 1745-1750. (doi:10.1007/s00125015-3608-6)

Moffett RC, Vasu S \& Flatt PR 2015 Functional GIP receptors play a major role in islet compensatory response to high fat feeding in mice. Biochimica et Biophysica Acta 1850 1206-1214. (doi:10.1016/j. bbagen.2015.02.006)

Mu J, Jiang G, Brady E, Dallas-Yang Q, Liu F, Woods J, Zycband E, Wright M, Li Z, Lu K, et al. 2011 Chronic treatment with a glucagon receptor antagonist lowers glucose and moderately raises circulating glucagon and glucagon-like peptide 1 without severe alpha cell hypertrophy in diet-induced obese mice. Diabetologia 54 2381-2391. (doi:10.1007/s00125-011-2217-2)

Nauck MA, Homberger E, Siegel EG, Allen RC, Eaton RP, Ebert R \& Creutzfeldt W 1986 Incretin effects of increasing glucose loads in man calculated from venous insulin and C-peptide responses. Journal of Clinical Endocrinology and Metabolism 63 492-498. (doi:10.1210/ jcem-63-2-492)

Nauck MA, Heimesaat MM, Orskov C, Holst JJ, Ebert R \& Creutzfeldt W 1993 Preserved incretin activity of glucagon-like peptide 1 [7-36 amide] but not of synthetic human gastric inhibitory polypeptide in patients with type-2 diabetes mellitus. Journal of Clinical Investigation 91 301-307. (doi:10.1172/JCI116186)

O'Harte FPM, Franklin ZJ, Rafferty EP \& Irwin N 2013 Characterisation of structurally modified analogues of glucagon as potential glucagon receptor antagonists. Molecular \& Cellular Endocrinology 38 26-34. (doi:10.1016/j.mce.2013.07.014)

O'Harte FPM, Irwin M \& Franklin ZJ 2014 Two novel glucagon receptor antagonists prove effective therapeutic agents in high-fat-fed and obese diabetic mice. Diabetes, Obesity \& Metabolism 12 1214-1222. (doi:10.1111/dom.12360)

Parker JC, Andrews KM, Allen MR, Stock JL \& McNeish JD 2002 Glycemic control in mice with targeted disruption of the glucagon receptor gene. Biochemical Biophysical Research Communications 290 839-843. (doi:10.1006/bbrc.2001.6265) http://joe.endocrinology-journals.org

DOI: $10.1530 / \mathrm{JOE}-15-0463$
(C) 2016 Society for Endocrinology Printed in Great Britain
Published by Bioscientifica Ltd. 
Patel V, Joharapurkar A, Dhanesha N, Kshirsagar S, Patel K, Bahekar R, Shah G \& Jain M 2013 Co-agonist of glucagon and GLP-1 reduces cholesterol and improves insulin sensitivity independent of its effect on appetite and body weight in diet-induced obese C57 mice. Canadian Journal of Physiology and Pharmacology 91 1009-1015. (doi:10.1139/cjpp-2013-0189)

Peng JZ, Denney WS, Musser BJ, Liu R, Tsai K, Fang L, Reitman ML, Troyer MD, Engel SS, Xu L, et al. 2014 A semi-mechanistic model for the effects of a novel glucagon receptor antagonist on glucagon and the interaction between glucose, glucagon, and insulin applied to adaptive phase II design. American Association of Pharmaceutical Scientists Journal 16 1259-1270. (doi:10.1208/s12248-014-9648-x)

Pernicova I \& Korbonits M 2014 Metformin - mode of action and clinical implications for diabetes and cancer. Nature Reviews of Endocrinology 10 143-156. (doi:10.1038/nrendo.2013.256)

Petersen KF \& Sullivan JT 2001 Effects of a novel glucagon receptor antagonist (Bay 27-9955) on glucagon-stimulated glucose production in humans. Diabetologia 44 2018-2024. (doi:10.1007/s001250100006)

Piteau S, Olver A, Kim SJ, Winter K, Pospisilik JA, Lynn F, Manhart S, Demuth HU, Speck M, Pederson RA \& McIntosh CH 2007 Reversal of islet GIP receptor down-regulation and resistance to GIP by reducing hyperglycemia in the Zucker rat. Biochemical and Biophysical Research Communications 362 1007-1012. (doi:10.1016/j.bbrc.2007.08.115)

Porter DW, Irwin N, Flatt PR, Hölscher C \& Gault VA 2011 Prolonged GIP receptor activation improves cognitive function, hippocampal synaptic plasticity and glucose homeostasis in high-fat fed mice. European Journal of Pharmacology 650 688-693. (doi:10.1016/j.ejphar.2010.10.059)

Sehgal A, Vaishnaw A \& Fitzgerald K 2013 Liver as a target for oligonucleotide therapeutics. Journal of Hepatology 59 1354-1359. (doi:10.1016/j.jhep.2013.05.045)

Skarbaliene J, Secher T, Jelsing J, Ansarullah J, Neerup TS, Billestrup N \& Fosgerau K 2015 The anti-diabetic effects of GLP-1-gastrin dual agonist ZP3022 in ZDF rats. Peptides 69 47-55. (doi:10.1016/j. peptides.2015.03.024)

Sturm NS, Lin Y, Burley SK, Krstenansky JL, Ahn JM, Azizeh BY, Trivedi D \& Hruby VJ 1998 Structure-function studies on positions 17, 18, and
21 replacement analogues of glucagon: the importance of charged residues and salt bridges in glucagon biological activity. Journal of Medicinal Chemistry 41 2693-2700. (doi:10.1021/jm980084a)

Trevaskis JL, Mack CM, Sun C, Soares CJ, D'Souza LJ, Levy OE, Lewis DY, Jodka CM, Tatarkiewicz K, Gedulin B, et al. 2013 Improved glucose control and reduced body weight in rodents with dual mechanism of action peptide hybrids. PloS ONE 8 e78154. (doi:10.1111/dom.12360)

Trujillo JM \& Nuffer W 2014 GLP-1 receptor agonists for type 2 diabetes mellitus: recent developments and emerging agents. Pharmacotherapy 34 1174-1186. (doi:10.1002/phar.1507)

Unger RH \& Cherrington AD 2012 Glucagonocentric restructuring of diabetes: a pathophysiologic and therapeutic makeover. Journal of Clinical Investigation 122 4-12. (doi:10.1172/JCI60016)

Unson CG, Macdonald D, Ray K, Durrah TL \& Merrifield RB 1991 Position 9 replacement analogs of glucagon uncouple biological activity and receptor binding. Journal of Biological Chemistry 266 2763-2766.

Unson CG, Macdonald D \& Merrifield RB 1993 The role of histidine-1 in glucagon action. Archives Biochemistry and Biophysics 300 747-750. (doi:10.1006/abbi.1993.1103)

Vilsbøll T, Krarup T, Deacon CF, Madsbad S \& Holst JJ 2001 Reduced postprandial concentrations of intact biologically active glucagonlike peptide 1 in type 2 diabetic patients. Diabetes 50 609-613. (doi:10.2337/diabetes.50.3.609)

Widenmaier SB, Kim SJ, Yang GK, De Los Reyes T, Nian C, Asadi A, Seino Y, Kieffer TJ, Kwok YN \& McIntosh CH 2010 A GIP receptor agonist exhibits b-cell anti-apoptotic actions in rat models of diabetes resulting in improved b-cell function and glycemic control. PLOS ONE 5 e9590. (doi:10.1371/journal.pone.0009590)

Xiong Y, Guo J, Candelore MR, Liang R, Miller C, Dallas-Yang Q, Jiang G, McCann PE, Qureshi SA, Tong X, et al. 2012 Discovery of a novel glucagon receptor antagonist N-[(4-\{(1S)-1-[3-(3,5dichlorophenyl)-5-(6-methoxynaphthalen-2-yl)-1H-pyrazolyl]ethyl phenyl) carbonyl]- $\beta$-alanine (MK-0893) for the treatment of type II diabetes. Journal of Medicinal Chemistry 55 6137-6148. (doi:10.1021/ jm300579z)

Received in final form 14 March 2016

Accepted 19 April 2016

Accepted Preprint published online 20 April 2016
(C) 2016 Society for Endocrinology Printed in Great Britain 